\title{
APLIKASI CERITA PENDEK TENTANG PENERAPAN NEW NORMAL COVID-19 PADA ANAK-ANAK MENGGUNAKAN AUGMENTED REALITY BERBASIS ANDROID
}

\author{
Jimmy H. Moedjahedy ${ }^{1}$, Okky Meiler Sigar ${ }^{2}$ \\ Dosen Universitas Klabat ${ }^{1}$, Mahasiswa Universitas Klabat ${ }^{2}$ \\ Jl. Arnold Mononutu, Airmadidi, Minahasa Utara, Sulawesi Utara, 95371 \\ Sur-el: jimmy@unklab.ac.id ${ }^{1}, 11510303 @$ student.unklab $^{2}$
}

\begin{abstract}
The new virus known as Covid-19 has caused many deaths around the world, even in our own country, Indonesia. It began in China, when the virus spread around the world, many people became victims and caused widespread concern among humans. This becomes a new routine for all humans in the world where everyone including children must run this health protocol every day. Children know more about games or entertainment content from the internet. This makes children rule out the importance of health protocols. By combining Augmented Reality technology with short stories about the spread of the new normal on Android devices, it can help children learn about the importance of healthy living in more exciting ways. Augmented reality is a technology that combines virtual and physical elements in real time. Interactive technologies such as Augmented Reality can be a big attraction for children, because it can be seen from the development and advancement of this technology gets special attention from children living in today's millennial era Based on this, researchers developed a short story application about the application of new normal in children, which utilizes android-based augmented reality technology to display $3 D$ versions of short stories based on detection results. existing markers. As a result of this study, it is expected that children can be interested and easily apply a healthy lifestyle in the pandemic era.
\end{abstract}

Keywords: Android, Augmented Reality, 3D, game, marker, new normal

\begin{abstract}
Abstrak: Virus baru yang dikenal sebagai Covid-19 telah menyebabkan banyak kematian di seluruh dunia, bahkan di negara kita sendiri, Indonesia. Ini dimulai di Cina, ketika virus menyebar ke seluruh dunia, banyak orang menjadi korban dan menyebabkan kekhawatiran luas di antara manusia. Hal ini menjadi sebuah rutinitas baru untuk seluruh manusia di dunia dimana semua orang termasuk anak-anak harus menjalankan protokol kesehatan ini sehari-hari. Anak-anak lebih banyak tahu soal game atau konten-konten hiburan dari internet. Hal ini membuat anak-anak mengesampingkan pentingnya protokol kesehatan. Dengan menggabungkan teknologi Augmented Reality dengan cerita pendek tentang penyebaran new normal di perangkat Android, dapat membantu anak-anak belajar tentang pentingnya hidup sehat dengan cara yang lebih menarik. Augmented reality adalah teknologi yang menggabungkan elemen virtual dan fisik secara real time. Teknologi interaktif seperti Augmented Reality dapat menjadi daya tarik yang begitu besar bagi anak-anak, karena bisa dilihat dari perkembangan dan kemajuan teknologi ini mendapat perhatian khusus dari anak-anak yang hidup pada zaman milenial saat ini Berdasarkan hal ini, peneliti mengembangkan aplikasi cerita pendek tentang penerapan new normal pada anak-anak, yang memanfaatkan teknologi augmented reality berbasis android untuk menampilkan versi $3 D$ dari cerita pendek berdasarkan hasil deteksi penanda yang ada. Sebagai hasil dari penelitian ini, diharapkan anak-anak dapat tertarik dan dengan mudah menerapkan pola hidup sehat pada era pandemic.
\end{abstract}

Kata kunci: Android, Augmented Reality, 3D, game, marker, new normal

\section{PENDAHULUAN}

Virus corona adalah keluarga besar virus yang menyebabkan penyakit mulai dari ringan hingga cukup parah hingga berakibat fatal. Hingga saat ini, virus corona telah diklasifikasikan menjadi tiga kategori, yang masing-masing menyebabkan gejala parah termasuk Middle East Respiratory Syndrome 
(MERS), severe acute respiratory syndrome (SARS) dan Corona Virus Disease 2019 (COVID-19) [1]. COVID-19 adalah sebuah wabah yang bukan menjadi masalah nasional saja, tapi sudah merupakan masalah global. Dilansir dari data laporan mingguan operasional WHO, hingga saat ini sudah ada 44.888.869 kasus dan 1.178.475 kematian yang terkonfirmasi secara global [2]. Begitu banyak cara dilakukan pemerintah dalam menghentikan penyebaran Virus yang mematikan ini. Mulai dari melarang semua kegiatan yang melibatkan orang dimana dapat melakukan kontak fisik, menutup semua instansi-instansi besar yang pengoperasiannya dapat membuat para warga melakukan kontak fisik, larangan-larangan pertemuan dalam komunitas-komunitas kecil, bahkan sekolah yang adalah tempat belajar dan tempat dimana para murid dan guru dapat berinteraksi secara langsung dengan baik ini ditutup.

Di Indonesia saat ini new normal telah di terapkan pada masyarakat Indonesia. Masyarakat dapat melakukan kegiatan sehari-hari dalam pekerjaan dan kegiatan-kegiatan keseharian yang biasanya dilakukan, tetapi harus mengikuti protokol kesehatan yang ketat, yaitu melakukan semua hal dengan fokus pada kesehatan dan kebersihan, dengan cara yang sederhana yaitu cuci tangan setiap saat dan memakai masker .

Penerapan untuk cuci tangan dan pakai masker ini adalah hal paling sederhana yang dapat dilaksanakan. Namun, ternyata hal yang dianggap sederhana dan gampang di lakukan masyarakat dalam keseharian mereka ini, masih saja dianggap tak serius oleh masyarakat
Indonesia, dimana masih ada saja beberapa masyarakat masih tak membiasakan untuk mencuci tangan dan memakai masker, terlebih khususnya pada anak-anak yang adalah generasi berikutnya dan sebagai penerus bangsa kita dimana hal ini sangat lah penting untuk di terapkan sebagaimana tertulis dalam lampiran pedoman penggunaan masker untuk anak-anak di masyarakat sesuai dengan COVID-19, yang telah dikonsultasikan dengan WHO Health Emergencies Programme (WHE) dan para pakar dari United Nations Children's Fund (UNICEF).

Ada beberapa aplikasi berbasis Augemented Reality yang dikembangkan yang memiliki topik terkait Covid-19 tetapi cenderung lebih ke cara pembelajaran pada masa [3], [4], [5], [6], [7], [8], [9], [10], [11], [12] dan [13] bukan pengenalan akan penerapan new normal. Teknologi interaktif seperti Augmented Reality dapat menjadi daya tarik yang begitu besar bagi anak-anak, karena bisa dilihat dari perkembangan dan kemajuan teknologi ini mendapat perhatian khusus dari anak-anak yang hidup pada zaman milenial saat ini. Anak-anak yang begitu menyukai hal-hal yang instan pada teknologi dan memiliki kegiatan yang memprioritaskan smartphone dalam kehidupan sehari-hari [14]. Ini mendukung bukti bahwa anak-anak akan mendapat daya tarik yang lebih ketika penerapan New Normal ini dapat di sosialisasikan melalui teknologi Augmented Reality agar anak-anak dapat lebih memiliki fokus yang lebih dalam menjalankan protokol kesehatan. 


\section{METODOLOGI PENELITIAN}

Pada bab ini membahas tentang ruang lingkup dan metode penelitian

\subsection{Ruang Lingkup}

Berdasarkan latar belakang yang telah dijelaskan secara rinci diatas, maka perumusan masalah yang dapat di ambil adalah, Bagaimana mengimplementasikan teknologi Augmented Reality ke dalam sebuah cerita pendek menarik untuk penerapan protokol kesehatan berbasis android.

Adapun cakupan penelitian yang ditentukan oleh peneliti dalam membangun aplikasi ini adalah:

1. Membuat buku kecil berisi marker dengan total 32 marker yang memproyeksikan cerita pendek tentang pentingnya cuci tangan dan pakai masker.

2. Menampilkan karakter-karakter dalam bentuk objek 3D di Augmented Reality yaitu: Karakter utama bernama boy (menggambarkan anak-anak), karakter pembantu yaitu Mask Shield/Perisai Masker (menggambarkan Masker), The Secret Weapon/Senjata Rahasia (menggambarkan keran air), Water Ammo/Peluru Air (menggambarkan air), Special Ammo/Peluru Spesial (menggambarkan sabun) dan Corona Army (menggambarkan Virus Corona yang menyerang), serta karakterkarakter objek lainnya, objek kertas virtual yang berisi deskripsi cerita, serta objek gambar yang memproyeksikan si pemeran utama yaitu boy telah berhasil terhindar dari Virus Corona.

3. Karakter-karakter dalam cerita anak-anak ditampilkan dalam bentuk augmented reality yang dapat menyesuaikan sudut pandang dari user dimana user dapat melihat objek dari berbagai sisi kecuali dari bawah buku, atau dimana marker tidak terlihat.

Peneliti memberikan batasan dalam penelitian ini yaitu:

1. Aplikasi ini hanya dapat memindai 1 marker.

2. Objek yang di proyeksikan tidak di sertakan dengan suara/audio.

3. Smartphone harus Android minimum versi Kitkat dan memiliki sensor gyroscope dan accelerometer.

Adapun penelitian-penelitian yang terkait dengan topik yang sama yaitu mencoba untuk membawakan cerita dalam bentuk Augmented Reality. Penelitian yang dilakukan [15] dengan topik media pembelajaran berupa buku cerita bergambar berbasis Augmented Reality. Selanjutnya [15] membuat penelitian dengan topik Legenda Asal Mula Selat Bali mengunakan Augmented Reality. Berikutnya yang dilakukan oleh [15] dengan topik buku cerita anti korupsi berbasis Augmented Reality. Terakhir yang dilakukan oleh [18] dengan judul Terapan Augmented Reality Untuk Buku Cerita "Petualangan Jaka Aksara".

\section{$2.2 \quad$ Metode}

Model pada penelitian ini adalah proses prototyping model. Prototyping adalah teknik 
untuk mengelola siklus hidup sistem yang didasarkan pada konsep model kerja. Teknik model ini digunakan untuk mengubah model menjadi sistem yang lengkap. Prototyping membantu dalam mengidentifikasi persyaratan di awal proses pengembangan.Siklusnya dapat dilihat pada gambar 1 .

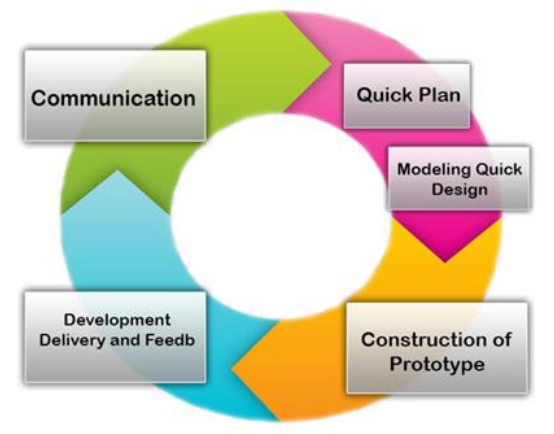

Gambar 1. Model Prototyping

Berikut ini adalah penjelasan dari setiap fase dalam kerangka konseptual para peneliti untuk penelitian mereka :

\section{Communication}

Pada tahap ini peneliti mengumpulkan data dan informasi sebagai persyaratan awal untuk membuat aplikasi. Informasi diperoleh dengan cara studi literatur dan observasi tidak langsung.

\section{Quick plan dan Modeling Quick Design}

Pada tahap ini, peneliti mempersiapkan segala sesuatu mulai dari desain layar hingga bahasa pemrograman yang akan digunakan, serta perangkat lunak yang akan membantu dalam membuat aplikasi, objek 3D, dan tanda yang divisualisasikan dalam augmented reality.

\section{Construction of Prototype}

Peneliti mengevaluasi dan mulai merancang sistem pada tingkat ini. Peneliti menilai sistem saat ini dalam aplikasi yang dirancang menggunakan diagram UML. Kemudian mulai mengembangkan prototipe dasar aplikasi.

4. Deployment delivery dan feedback

Pada tahap terakhir ini prototype di uji coba langsung pada pengguna dan di evaluasi langsung oleh pengguna. Setelah di evaluasi pengguna akan memberi feedback dimana aplikasi ini akan di kembangkan lebih lanjut sesuai keinginan pengguna [19].

\subsection{Arsitektur Aplikasi}

Tahap yang digambarkan dalam Gambar 2 adalah yang terjadi selama penggunaan aplikasi oleh pengguna.

1. Pengguna mengakses aplikasi lewat smartphone yang telah diinstal.

2. Melihat tampilan dengan menyalakan kamera.

3. Marker yang tersedia, dibaca dengan menggunakan kamera tersebut.

4. Kamera mendeteksi dataset penanda.

5. Setelah mendeteksi dataset penanda, informasi diberikan.

6. Data yang diberikan menghasilkan output dalam bentuk objek tiga dimensi yang berasal dari halaman buku.

7. Pada layar smartphone, output yang dihasilkan disajikan

8. Smartphone menampilkan objek 3D kepada user. 


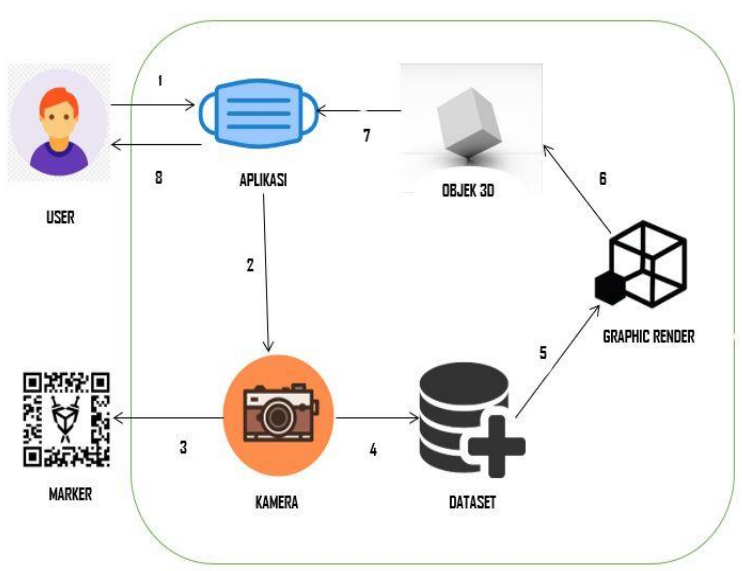

Gambar 2. Arsitektur Aplikasi

\subsection{Diagram UML}

Diagram UML yang digunakan dalam penelitian ini adalah use case diagram dan class diagram.

\subsubsection{Use Case Diagram}

Diagram Use Case digunakan untuk menggambarkan interaksi antara pengguna dan aplikasi; Juga, peneliti menggambarkan setiap use case yang ada dalam aplikasi pada gambar 3 .

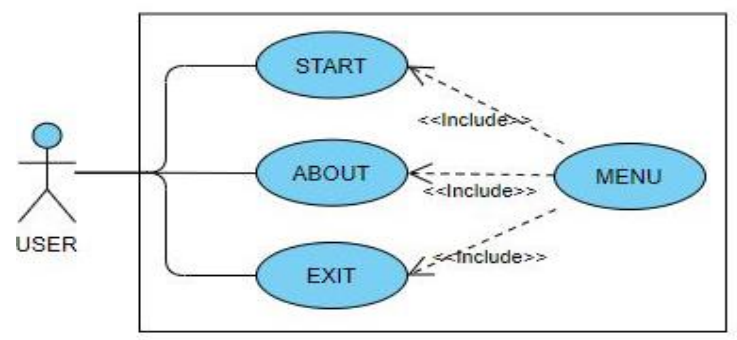

\section{Gambar 3. Use Case Diagram}

Nama Use Case: Start

Aktor : User

Deskripsi : Menampilkan pilihan untuk memulai cerita dengan menunjukkan kamera dalam memindai gambar yang menunjukkan karakter serta tulisan pendek cerita.

Kondisi awal : User sudah masuk ke aplikasi
Kondisi akhir : User dapat melakukan scan pada marker dan melihat 3D object serta cerita yang dimaksud.

Langkah-langkah yang dilakukan:

1. User memilih menu.

2. User memilih "Start".

3. .Sistem ini menampilkan layar yang menunjukkan bahwa kamera siap untuk memindai objek di halaman buku.

\section{Nama Use Case: About}

Deskripsi : User memilih menu About

Kondisi awal : Ketika tombol about diakses akan tampil deskripsi tentang aplikasi

Kondisi akhir : Deskripsi mengenai aplikasi dapat dilihat.

Langkah-langkah yang dilakukan

1. Membuka aplikasi

2. Menekan tombol about

3. Nama Use Case : Exit

Deskripsi : menutup aplikasi

Kondisi awal : User sedang menggunakan aplikasi

Kondisi akhir : User terlah berhasil menutup aplikasi

Langkah-langkah yang dilakukan

1. Menekan tombol keluar.

2. Aplikasi langsung tertutup

\subsubsection{Class Diagram}

Diagram kelas adalah representasi dari kelas yang dibuat aplikasi dan fungsi terkaitnya, seperti yang ditunjukkan pada gambar 4 .

1. Bagian Menu Kelas dari menu utama aplikasi menampilkan menu Kamera, Tentang, dan Keluar. 
2. Class Begin, di mana kamera memindai objek dalam sebuah buku dan menunjukkan objek.

3. Kelas ini memberikan informasi tentang aplikasi dan peneliti.

4. Kelas Exit berisi metode untuk keluar dari aplikasi.

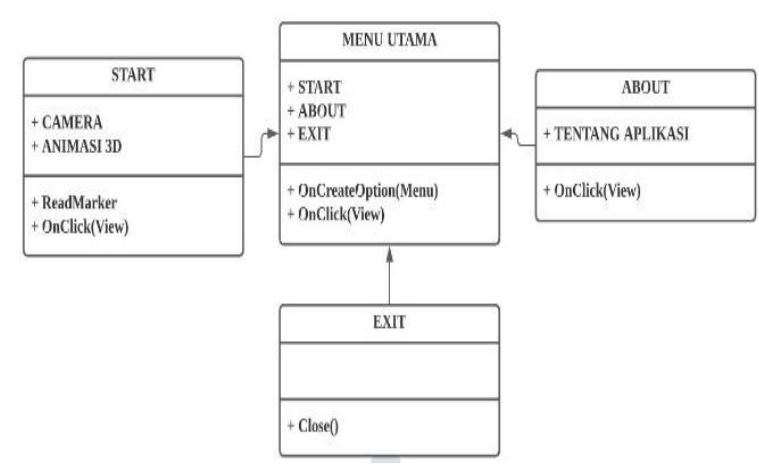

Gambar 4. Class Diagram

\section{HASIL DAN PEMBAHASAN}

Pada bagian ini akan dibahas tampilan antarmuka dari aplikasi, cerita dan pengujian aplikasi.

\subsection{Tampilan antar muka dan cerita}

Berikut merupakan tampilan antarmuka dari aplikasi cerita pendek tentang penerapan 'new normal' pada anak-anak menggunakan augmented reality berbasis android. Jalan ceritanya adalah sebagai berikut.

Di bumi yang sudah menjadi begitu suram dan gelap oleh karena Corona Army, banyak sekali manusia yang telah pasrah, menyerah dan terpuruk karena Corona Army telah berhasil menyerang dan menguasai dunia dengan mengambil semua yang kita sayangi dan kita cintai.
Tak ada yang berani melawan dan memilih untuk tetap diam dengan membiarkan Corona Army mengambil alih dunia, akan tetapi tidak dengan seorang anak yang bernama Boy. Dia memiliki keberanian yang sebenarnya bisa dimiliki semua anak di dunia jika saja semua anak memiliki tekad untuk menunjukan bahwa seorang anak kecil berani untuk memberantas Corona Army. "majulah kalian semua corona army! aku tidak takut dengan kalian." Seru si Boy dengan berani. Corona Army dengan jumlah pasukannya yang sangat banyak itu langsung menyerang si Boy. Benar saja si Boy kalah karena dia tidak memiliki apapun selain keberanian.

Keberanian si Boy membuat para manusia bergerak untuk membantu si Boy dengan memberikan Boy Mask Shield, yaitu sebuah perisai kuat berbentuk masker berukuran besar yang dapat membuat Boy terlindungi dari serangan Corona Army. Tetapi Mask Shield hanya dapat melindungi si Boy saja, Mask Shield tidak dapat melindungi seluruh umat manusia.

"kita membutuhkan senjata yang dapat membuat Corona Army mati agar mereka tidak bisa lagi menyerang manusia. Apakah senjata ini bisa dibuat ?" Pinta si Boy kepada manusia.

"Boy... ada sebuah senjata yang mungkin saja bisa memberantas Corona Army ini" para manusia sembari memberikan sebuah senjata berbentuk keran air yang disebut The Secret Weapon serta peluru Water Ammo kepada Boy.

"The Secret Weapon? bagaimana mungkin, tidak terpikir sebelumnya bahwa 
sebuah senjata keran air ini mungkin bisa saja memberantas Corona Army" kata Boy terheran.

Boy segera memasukkan Water Ammo ke dalam Senjata lalu menembakkan pada pasukan Corona. Ternyata serangan dari Boy berhasil mengalahkan Corona Army, tapi Corona Army hanya kalah dan tidak mati. Mereka bisa saja menyerang manusia lagi.

Saat itu Boy terpikir, jika kita mencuci benda kotor dengan hanya menggunakan air, maka benda itu tidak bersih dengan sempurna. Dia pun menyadari, jika peluru yang di tembakan hanya berupa air maka musuh tidak akan binasa. Boy segera mengambil sebuah sabun dan meraciknya menjadi Special Ammo, yaitu sebuah peluru spesial yang terbuat dari sabun.

Boy menggabungkan dua peluru yang di milikinya yaitu Water Ammo dan Special Ammo lalu menembakkannya pada pasukan Corona dan akhirnya mereka mati dan bumi pun bersih kembali. Dengan keberanian dan serangan menggunakan senjata serta peluru yang benar maka Corona Army bisa diberantas. Itulah semua hal yang dibutuhkan untuk dapat menghindari Corona Army.

Mask Shield, The Secret Weapon, Water Ammo dan Special Ammo serta keberanian di terapkan kepada manusia di seluruh dunia dan akhirnya semua manusia dapat terhindar dari Corona Army selamanya.

Gambar 5 dan gambar 6 merupakan tampilan ketika aplikasi dijalankan, dimana menampilkan menú yang ada serta keterangan pembuat aplikasi. Pada tabel 1 menunjukkan marker yang ada berikut hasil dari pindai marker dan nama scene.

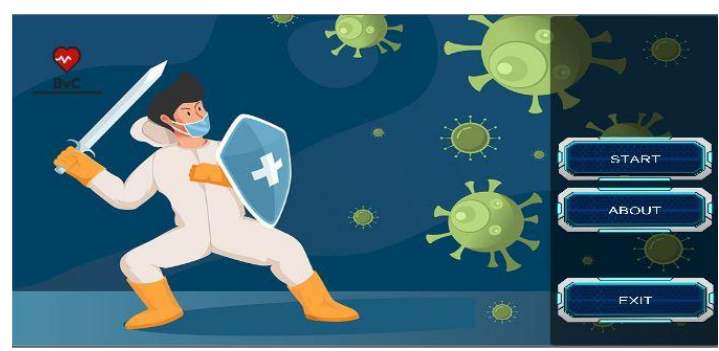

Gambar 5. Tampilan Menu Utama Aplikasi

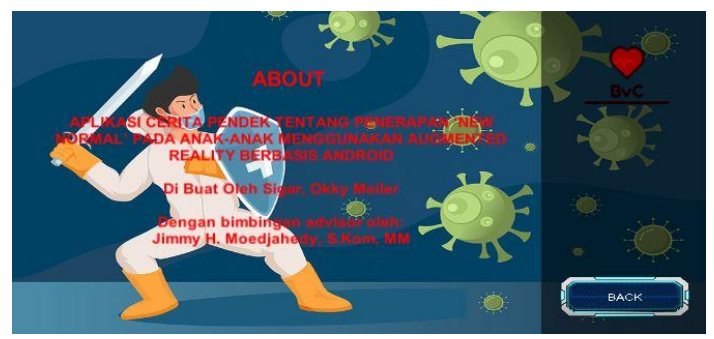

Gambar 6. Tampilan Menu About

Tabel 1. Marker dan Tampilan Objek

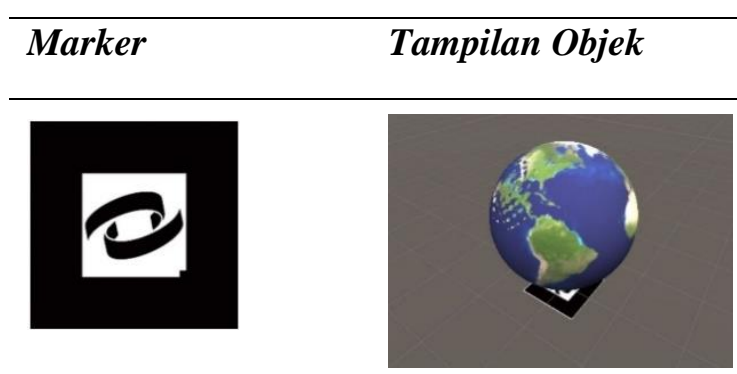

Scene 1 Bumi Bersih

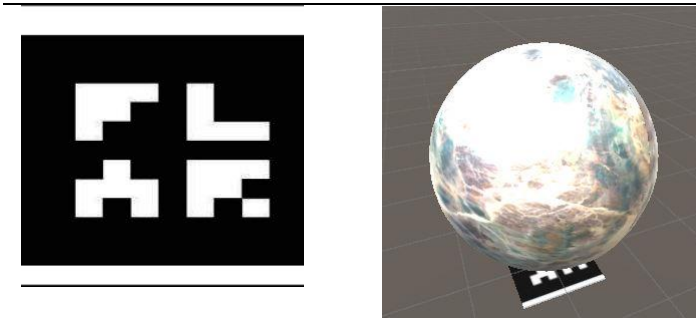

Scene 2 Bumi Rusak

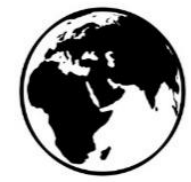

Scene 3 Corona Army

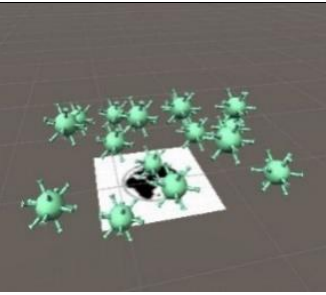



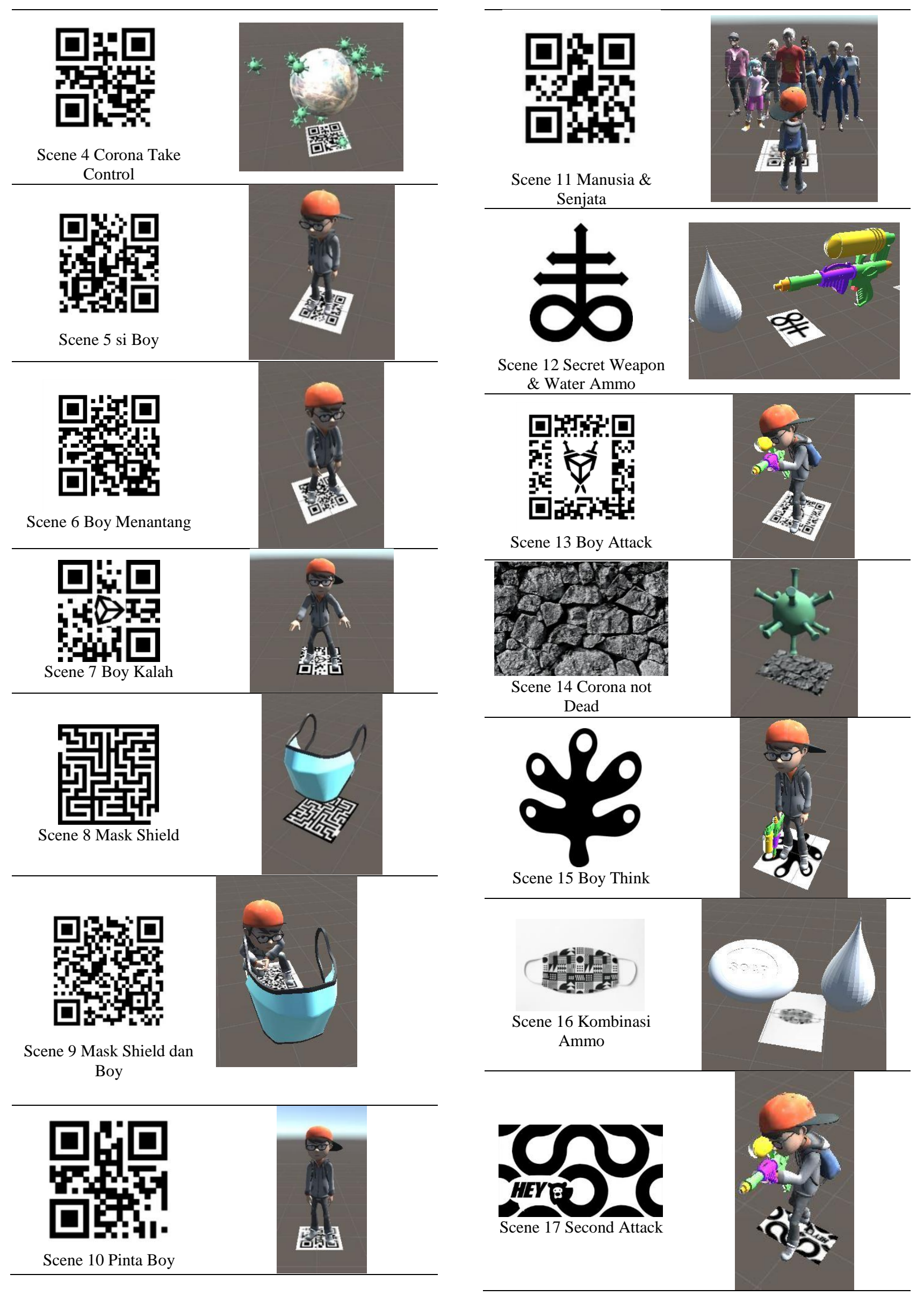

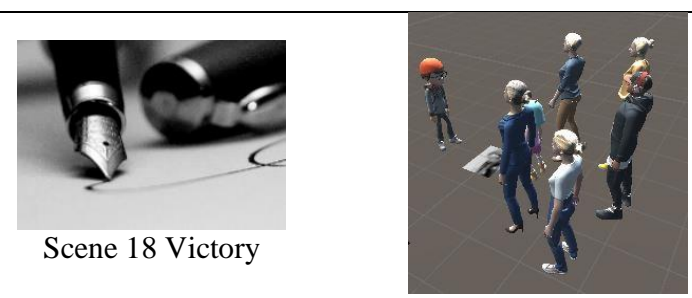

\subsection{Pengujian}

Pada langkah ini, peneliti menggunakan pendekatan Black Box Testing, yang melibatkan pengujian fungsi aplikasi menggunakan program pada perangkat Android. Black Box Testing, juga dikenal sebagai pengujian fungsional, adalah teknik pengujian perangkat lunak yang digunakan untuk mengevaluasi perangkat lunak tanpa pengetahuan tentang kode atau struktur internal program. Dalam tes ini, penguji memahami apa yang harus dilakukan program tetapi tidak yakin bagaimana mencapainya [20]. Tabel 2 berikut merangkum temuan tes yang dilakukan dengan menggunakan metode Pengujian Kotak Hitam:

Tabel 2. pengujian

\begin{tabular}{|c|c|c|}
\hline Deskripsi & $\begin{array}{ll}\text { Hasil } & \text { Yang } \\
\text { Diharapkan }\end{array}$ & Hasil Pengujian \\
\hline $\begin{array}{l}\text { Menekan } \\
\text { button Start } \\
\text { Gambar pada } \\
\text { menu utama }\end{array}$ & $\begin{array}{l}\text { Ketika penanda } \\
\text { dikenali, aplikasi } \\
\text { menampilkan cerita } \\
\text { pendek augmented } \\
\text { reality tentang } \\
\text { implementasi new } \\
\text { normal. }\end{array}$ & $\begin{array}{l}\text { menampilkan } \\
\text { tampilan kamera } \\
\text { dengan sukses. } \\
\text { Penanda } \\
\text { mendeteksi dan } \\
\text { menampilkan cerita } \\
\text { pendek augmented } \\
\text { reality mengenai } \\
\text { penerapan new } \\
\text { normal. }\end{array}$ \\
\hline $\begin{array}{l}\text { Menekan } \\
\text { button About } \\
\text { pada menu } \\
\text { utama }\end{array}$ & $\begin{array}{l}\text { Menampilkan } \\
\text { informasi dari } \\
\text { aplikasi. }\end{array}$ & $\begin{array}{l}\text { Informasi dari } \\
\text { aplikasi berhasil } \\
\text { ditampilkan }\end{array}$ \\
\hline $\begin{array}{l}\text { Menekan } \\
\text { button exit }\end{array}$ & Keluar dari aplikasi & $\begin{array}{l}\text { Berhasil keluar dari } \\
\text { aplikasi }\end{array}$ \\
\hline
\end{tabular}

Setelah tes fungsional aplikasi, peneliti melakukan tes untuk menentukan keterampilan deteksi aplikasi terhadap penanda. Peneliti melakukan dua pengujian, yaitu pengujian pencahayaan pada tabel 3 dan pengujian jarak pada tabel 4 saat mendeteksi marker.

Tabel 3. Pengujian Cahaya

\begin{tabular}{lll}
\hline & MINIMAL $(\boldsymbol{l x})$ & MAXIMAL $(\boldsymbol{l x})$ \\
\hline Percobaan 1 & 1 & 8 \\
Percobaan 2 & 4 & 21 \\
Percobaan 3 & 28 & 362 \\
Percobaan 4 & 1.180 & 1.700 \\
Percobaan 5 & 1.307 & 16.705 \\
\hline
\end{tabular}

Tabel 4. Pengujian Jarak

\begin{tabular}{ll}
\hline Jarak (cm) & Hasil \\
\hline $15 \mathrm{~cm}$ & Terdeteksi \\
$20 \mathrm{~cm}$ & Terdeteksi \\
$25 \mathrm{~cm}$ & Terdeteksi \\
$35 \mathrm{~cm}$ & Tidak Terdeteksi \\
\hline
\end{tabular}

\section{KESIMPULAN}

Dari hasil penelitian untuk pembuatan aplikasi cerita pendek tentang penerapan new normal pada anak-anak menggunakan augmented reality berbasis android dapat disimpulkan bahwa aplikasi ini dapat dijalankan pada android versi Kitkat, sampai dengan Nougat, dapat menampilkan augmented reality dari semua halaman buku yang ada dengan menggunakan 18 marker, 1 untuk setiap Halaman buku yang bergambar di sebelah kanan dan status cerita yang mewakili scene terkini. Berdasarkan hasil pengujian dari metode Black Box Testing maka aplikasi sudah bisa dibilang layak digunakan untuk memenuhi tujuan dari kasus penerapan new normal pada anak-anak.

\section{DAFTAR PUSTAKA}

[1] Direktorat Jenderal Pencegahan dan Pengendalian Penyakit (P2P), "Pedoman Pencegahan dan Pengendalian Corona Virus 
Disease (COVID-19)," 2020. https://infeksiemerging.kemkes.go.id/downl oad/REV-04_Pedoman_P2_COVID-

19_27_Maret2020_TTD1.pdf (accessed Sep. 18, 2021).

[2] World health Organization, "Weekly Operational Update on COVID-19," 2020. https://www.who.int/docs/default-

source/coronaviruse/situation-reports/wou4-september-2020-approved.pdf (accessed Sep. 20, 2021).

[3] I. Ummah and M. R. Ariwibowo, "Augmented Reality Sebagai Media Pendukung Pembelajaran Masa Pandemi COVID-19," Sci. Tech J. Ilmu Pengetah. dan Teknol., vol. 7, no. 1, 2021, doi: 10.30738/jst.v7i1.8901.

[4] J. S. Salim, F. A. Darmawan, "Augmented Reality-based Mathematics Worksheet for Online Learning During Covid-19 Pandemic," IJES Indones. J. Educ. Stud., vol. 23, no. 2, 2020.

[5] D. Pradiatiningtyas, "KONSEP Augmented Reality Dan Mobile Marketing Sebagai Usaha Pengembangan Pariwisata Yogyakarta Di Era Pandemi COVID 19," J. Pariwisata, vol. 8, no. 1, 2021, doi: 10.31294/par.v8i1.10464.

[6] M. R. A. Inayatul Ummah, "Augmented Reality Sebagai Media Pendukukung Pembelajaran Masa Pandemi Covid-19 Augmented Reality as Learning Support Media for Covid-19 Pandemic," Hum. Relations, vol. 3, no. 1, 2020.

[7] F. I. Dinillah, G. Janti, and P. Sinansari, "Penggunaan Augmented Reality Dan Perilaku Konsumen Dalam Berbelanja Kosmetik Selama Pandemi Covid-19," J. Sains Dan Seni ITS, vol. 10, no. 1, 2021.

[8] S. Et. al., "Augmented Reality Blended Learning Instruction: The Impact on Growing Motivation, Attitudes, and Knowledge in 3D Geometry," Turkish J. Comput. Math. Educ., vol. 12, no. 4, 2021, doi: 10.17762/turcomat.v12i4.552.

[9] M. Paat, H. Sutopo, and N. Siregar, "Developing augmented reality application on komodo dragon for elementary school children during the new normal of covid-19 pandemic," J. Theor. Appl. Inf. Technol., vol. 99, no. 11, 2021.

[10] J. Luck, N. Gosling, S. Saour, and J. Luck, "Undergraduate surgical education during COVID-19: Could augmented reality provide a solution?," British Journal of Surgery, vol. 108. 2021, doi: 10.1093/BJS/ZNAA159.

[11] S. R. Billewar et al., "The rise of 3D ECommerce: the online shopping gets real with virtual reality and augmented reality during COVID-19," World J. Eng., 2021, doi: 10.1108/WJE-06-2021-0338.

[12] A. A. Eldokhny and A. M. Drwish, "Effectiveness of Augmented Reality in Online Distance Learning at the Time of the COVID-19 Pandemic," Int. J. Emerg. Technol. Learn., vol. 16, no. 9, 2021, doi: 10.3991/ijet.v16i09.17895.

[13] M. Saleem, S. Kamarudin, H. M. Shoaib, and A. Nasar, "Influence of augmented reality app on intention towards e-learning amidst COVID-19 pandemic," Interact. Learn. Environ., 2021, doi: 10.1080/10494820.2021.1919147.

[14] D. Atmajaya, "Implementasi Augmented Reality Untuk Pembelajaran Interaktif," Ilk. J. Ilm., vol. 9, no. 2, 2017, doi: 10.33096/ilkom.v9i2.143.227-232.

[15] A. H. Lubis and M. D. Dasopang, "Pengembangan Buku Cerita Bergambar Berbasis Augmented Reality untuk Mengakomodasi Generasi Z," J. Pendidik. Teor. Penelitian, dan Pengemb., vol. 5, no. 6, 2020, doi: 10.17977/jptpp.v5i6.13613.

[16] T. W. Natha, I. G. M. Darmawiguna, and I. K. R. Arthana, "Pengembangan Aplikasi Markerless Augmented Reality Legenda Asal Mula Selat Bali," JST (Jurnal Sains dan Teknol., vol. 7, no. 1, 2018, doi: 10.23887/jst-undiksha.v6i1.8786.

[17] F. D. Pramanta, U. U. Hasanah, and M. R. Kurniawan, "Pengembangan Buku Cerita Interaktif Anti-korupsi Berbasis Teknologi Augmented Reality," INTEGRITAS, vol. 4, no. $\quad 1, \quad 2018, \quad$ doi: 10.32697/integritas.v4i1.156.

[18] V. E. Sugiri and R. Cahyadi, "Terapan Augmented Reality Untuk Buku Cerita 'Petualangan Jaka Aksara,"” J. Multi Media dan IT, vol. 4, no. 2, 2020, doi: 10.46961/jommit.v4i2.333.

[19] R. S. Pressman, Software Engineering A Practitioner's Approach 7th Ed - Roger S. Pressman. 2009.

[20] E. Setiawan, U. Syaripudin, and Y. A. Gerhana, "Implementasi Teknologi Augmented Reality pada Buku Panduan Wudhu Berbasis Mobile. 